\title{
Els Kies: d'Holanda al Camp de Tarragona
}

\author{
Josep FÀbregas Roig* \\ Universitat Rovira i Virgili
}

\section{Resum}

Larribada dels comerciants holandesos Joan Kies i Arnold de Jäger a Catalunya s'emmarca en el canvi que es va produir en les relacions comercials entre Holanda i la Monarquia Hispànica arran del Tractat de Münster i en la recuperació que a partir de la segona meitat del segle XvII va començar a experimentar l'economia catalana. L'objectiu d'aquest estudi és aprofundir en l'activitat econòmica i les relacions socials dels Kies, una nissaga que inicialment es va situar a Barcelona i que posteriorment es va traslladar al Camp de Tarragona, on va adquirir el castell de Vila-seca, que va convertir en la seva residència $\mathrm{i}$ en un centre productor $\mathrm{i}$ on van viure els seus descendents.

Paraules clau: Catalunya, Camp de Tarragona, vinya, aiguardent, comerç.

\section{Los Kies: de Holanda al Camp de Tarragona}

\section{Resumen}

La llegada de los comerciantes holandeses Juan Kies y Arnoldo de Jäger a Cataluña se sitúa en el contexto de cambio que se produjo en las relaciones comerciales entre Holanda y la Monarquía Hispánica a raíz del Tratado de Münster y en la recuperación que, a partir de la segunda mitad del siglo XVII,

* Josep Fàbregas Roig és professor d'Història Moderna a la Universitat Rovira i Virgili de Tarragona. És collaborador del grup d'investigació Centre d'Estudis sobre Conflictes Socials (CECOS), de la mateixa Universitat. 
comenzó a experimentar la economía catalana. El objetivo del presente estudio es profundizar en la actividad económica y las relaciones sociales de los Kies, una familia que inicialmente se instaló en Barcelona y que más tarde se trasladó al Camp de Tarragona, donde adquirió el castillo de Vila-seca, que convirtió en su residencia y en un centro productor y en el cual vivieron también sus descendientes.

Palabras clave: Cataluña, Camp de Tarragona, viña, aguardiente, comercio.

\title{
The Kies: from Holland to Camp de Tarragona
}

\begin{abstract}
The arrival of the Dutch traders Juan Kies and Arnoldo de Jäger in Catalonia should be perceived in the context of changes that had been initiated in trade relations between Holland and the Spanish monarchy, which resulted from the Peace of Münster treaty, and the economic recovery that began in Catalonia in the mid-I7th century. The purpose of this paper is to analyze the commercial activities and social relations of the Kies family, who first lived in Barcelona and then decided to move to Camp de Tarragona and buy a castle in Vila-seca, which they converted into their residence and production centre and where, later, their descendants continued living.
\end{abstract}

Keywords: Catalonia, Camp de Tarragona, vineyard, liquor, trade.

\section{Introducció}

A Joan Kies, comerciant d'origen holandès i cap de la nissaga, li va tocar viure una època especialment convulsa per a Catalunya, amb els conflictes de finals del segle Xviı i la Guerra de Successió. Això ha fet que la seva persona s'hagi estudiat no només en afers econòmics, sinó també en assumptes polítics i militars, ja que a causa de la seva adscripció austriacista va ser represaliat. Per aquest motiu, prestigiosos historiadors de temàtica molt diversa — que trobarem en aquest treball— li han dedicat atenció. 
Les relacions comercials entre Holanda i la Monarquia Hispànica, durant els regnats de Felip II, Felip III i Felip IV, es van veure seriosament afectades pels enfrontaments entre ambdues nacions, i no va ser fins després del Tractat de Münster que es normalitzaren. La bona sintonia es va concretar en el nomenament de cònsols, per part dels Estats Generals neerlandesos — només tretze dies després de la ratificació dels acords—, destinats a Cadis, Sevilla, Màlaga, Alacant i Sant Sebastià, als quals més endavant s'afegiren els de Barcelona, Bilbao, Vigo i Canàries. La delicada situació existent entre Madrid i París i la crisi del comerç venecià a causa de les disputes amb l'Imperi Otomà, van ajudar a impulsar l'expansió neerlandesa pel Mediterrani. També hi va contribuir la notable demanda, tant en aquesta zona com al Bàltic, de productes colonials americans, fet que convertí Cadis en un punt estratègic. ${ }^{I}$

La presència de comerciants del nord d'Europa a Catalunya i els enfrontaments que a finals del segle XVII i començaments del XvIII van mantenir França i Holanda, facilitaren l'exportació de cítrics, sedes i, especialment, vi i aiguardent. Davant les dificultats de proveir-se en el mercat francès, anglesos i holandesos buscaren avituallar-se a Catalunya. El Principat, després de la Guerra dels Segadors, del conflicte amb

I. Ignacio López Martín, «Entre la guerra económica y la persuasión diplomática: el comercio mediterráneo como moneda de cambio en el conflicto hispano-neerlandés (I574-I609)», Cahiers de la Méditerranée, 7I (2005), pp. 8I-IIO. Ángel Alloza Aparicio, "Guerra económica y comercio europeo en Espańa, i6241674. Las grandes represalias y la lucha contra el contrabando», Hispania, LXV/I, 219 (2005), pp. 227-280. Jonathan I. IsRaEL, «España, los embargos españoles y la lucha por el dominio del comercio mundial, I585-I648", Revista de Historia Naval, 6, 23 (I988), pp. 89-I05. Manuel Herrero Sánchez, «La Monarquia hispánica y el Tratado de La Haya de I673", Diálogos Hispánicos, I6 (1995), pp. I03-II8. Manuel Herrero SÁnchez, El acercamiento Hispano-Neerlandés (I648-I678), CSIC, Madrid, 2000, pp. 62-63. Antonio Serrano de Haro, "España y la Paz de Ryswick. De la Paz de Nimega (I678) a la de Ryswick (I697)», Diálogos Hispánicos, I6 (I995), pp. II9-I38. Carmen SANZ Ayán, Estado, monarquía y finanzas. Estudios de historia financiera en tiempos de los Austrias, Centro de Estudios Políticos y Constitucionales, Madrid, 2004, p. I52 i 179. Ana Crespo Solana, "Cooperación y competencia políticoeconómica en la larga duración: Holanda en la ruta del Mediterráneo (I62I-I702)», Pedralbes, 38 (2018), pp. 19-49. 
França en el context de la Guerra dels Nou Anys i de la Revolta dels Barretines, i també de les pestes de mitjan segle i la plaga de llagosta del I684, havia començat a recuperar-se econòmicament. ${ }^{2}$

\section{Activitat econòmica a Catalunya i al Camp de Tarragona}

Joan Kies va iniciar l'activitat econòmica a Barcelona cap al I66I, coincidint amb la bonança esmentada. Més endavant ho va fer Arnold de Jäger, igualment holandès, amb qui va formar una companyia. Segons Isabel Lobato, el període entre el I672 i el I705 va ser el de l'activitat mercantil més intensa. El I677 van oficialitzar la seva societat, tot i que ja feia deu anys que colllaboraven. Importaven productes d'Holanda (espècies, tabac, sucre i colorants), feien d'intermediaris, comerciaven amb manufactures tèxtils, produïen aiguardent, participaven d'arrendaments fiscals i assegurances marítimes, i també eren proveïdors de l'exèrcit. ${ }^{3}$ L'abast de la seva actuació s'estenia per ports del litoral Medi-

2. Jaume Torras Elías, «Productes vitícoles i integració mercantil a Europa, ss. XVI-XVIII», a Món mediterrani. Jornades sobre la Viticultura a la Conca Mediterrània, Facultat de Filosofia i Lletres de Tarragona, Delegació de la Universitat de Barcelona, Tarragona, I995, pp. 527-535. Emili Giralt Raventós, «Del conreu de subsistència al conreu comercial», a E. Giralt Raventós, J. M. Salrach Marès, eds., Història agrària dels Països Catalans, vol. III, Edat Moderna, Fundació Catalana per a la Recerca i la Innovació, Barcelona, 2008, pp. 297-330. Carlos Martínez Shaw, «Los aguardientes catalanes en Dunkerke, algunos testimonios», a J. M. Usunáriz Garayoa, ed., Historia y humanismo: estudios en honor del profesor Dr. D. Valentín Vázquez de Prada, vol. 2, EUNSA, Pamplona, 2000, pp. I8I-I94. Josep M. SANS TravÉ, «Notes sobre la plaga de la llagosta de I686-1688 a Solivella (Conca de Barberà)", Aplec de Treballs, 5 (I983), pp. 23I-255. Antonio Domínguez OrTIZ, La sociedad española en el siglo XVII, vol. I, CSIC / Universidad de Granada, Granada, 1992, pp. 7I-75.

3. Isabel Lobato Franco, Compañias y negocios en la Cataluña preindustrial, Universidad de Sevilla, Sevilla, 1995, p. I88. Albert Garcia Espuche, Barcelona entre dues guerres: economia i vida quotidiana (I652-I7I4), Eumo, Vic, 2005, p. 296. Juan A. SÁNCHEZ BeLÉN, «El comercio de exportación holandés en el Mediterráneo español durante la regencia de doña Mariana de Austria», Espacio, Tiempo y Forma. Historia Moderna, 9 (1996), pp. 267-32I. Juan A. SÁNCHEZ BeLÉN, «El comercio holandés de 
terrani: Marsella, Gènova, Mallorca, així com el Maresme i el Camp de Tarragona. També van contribuir al comerç colonial amb remeses a Cadis i a Lisboa, una part de les quals tenien la destinació al nord d'Europa. ${ }^{4}$

El I690 Joan Kies es va casar amb Maria Àngela Sala — de la noblesa del Maresme_- , filla de Bernat Sala i de Magdalena Fontanella i neta de Joan Pere Fontanella, conseller en cap l'any I640.5 L'enllaç matrimonial i la colllaboració amb l'Administració l'ajudaren a obtenir, el I4 de juny de I692, el títol de cavaller. ${ }^{6}$

La descentralització que des del punt de vista econòmic es produïa a Catalunya i el dinamisme del Camp de Tarragona envers la viticultura devien ser un bon argument perquè Kies i Jäger, o Joseph Shallet, cònsol anglès a Barcelona, invertissin en aquesta demarcació; en el cas dels primers, la destinació de les seves inversions va ser Vila-seca.

En una data sense concretar de finals del segle xviı, Joan Kies va adquirir a l'arquebisbe de Tarragona el castell de Vila-seca. No hem pogut situar cronològicament aquesta transacció; per tant, el document que certifica la seva presència a la localitat va ser el de i678, quan van adquirir a Pere Rovira, un pagès de la localitat esmentada, un hort per installar-hi una oficina d'aiguardent. El seu valor era de vuitanta-dues lliures i deu sous, i per garantir-ne el bon funcionament van pactar amb els jurats la concessió de la meitat de l'aigua de la vila. Dos anys després acordaven la compra d'una segona finca a la mateixa po-

las especias en España en la segunda mitad del siglo XviI», Hispania, LXx, 236 (setembre-desembre 20I0), pp. 633-66o. Benet Oliva Ricós, La generació de Feliu de la Penya. Burgesia Mercantil i Guerra de Successió entre el Maresme i Barcelona, Edicions Universitat de Lleida, Lleida, 20OI, p. II8. Antoni Jordà FernándeZ, «Els ingressos fiscals de la Generalitat de Catalunya a la segona meitat del segle Xviı", Estudis Històrics i Documents dels Arxius de Protocols, x (1982), pp. 163-203.

4. Albert Garcia Espuche, Barcelona entre dues guerres, p. 299. Carlos Martínez Shaw, Catalunya en la carrera de Indias, Crítica, Barcelona, I98I, pp. 58-59.

5. Antoni Simón Tarrés, Pagesos, capellans i industrials de la Marina de la Selva, Curial, Barcelona, 1993, p. 22. Oliva Ricós, La generació de Feliu de la Penya, p. 73.

6. Pere Molas Ribalta, Comerç i estructura social a Catalunya $i$ València als segles XVII $i$ XVIII, Curial, Barcelona, I977, p. I69. 
blació.7 El I685, en competència amb Shallet, Kies aconseguia l'arrendament del castell i les terres de Mascalbó, situades al terme de Reus, igualment per posar-hi una fabrica d'aiguardent. ${ }^{8}$ Les iniciatives de Joan Kies al Camp van comportar contactar amb pagesos i proveïdors del territori, que li van permetre alimentar les seves fabriques d'aiguardent. Entre el I682 i el I688 hem localitzat fins a quaranta-tres escriptures de compra de most, amb un total de set-centes setanta càrregues. La totalitat de les partides procedien de localitats del Camp de Tarragona properes a les seves fabriques. Entre les remeses destaquem les dues que va adquirir a Isidre Gran i Sebastià Pinyol, veïns de la Canonja, de cent càrregues cada una, i la de Josep Puig, veí de Vila-seca, de cinquanta-set. El preu que va abonar per càrrega, força estable al llarg dels anys, es va mantenir entre nou i deu rals, amb l'excepció del vi que va comprar a la Canonja, que va pagar a quinze; el preu incloïa el cost del transport fins a Vila-seca. Altres localitats proveïdores van ser Reus, Riudoms, Vilafortuny, Vilallonga del Camp i Vinyols. ${ }^{9}$

7. Arxiu Històric Arxidiocesà de Tarragona (AHAT), Parròquia de Sant Esteve de Vila-seca, Manuale secundum diversorum instrumentorum continuatum per me licenciatum Joannem Aragones, rectorem ac notarium publicum presentis parroquialis ecclesie Sancti Stephani Villesicce, campi et diocesi Tarragonem a die 6 mensis januarii I668, àpoca, 3I d'agost de 1678; Conveni amb els jurats de Vila-seca en relació a l'ús d'aigua i importació de vi, 31 d'agost de 1678; Manual d'actes $i$ àpoques $i$ altres instruments rebuts en mon poder de mi Joan Molner en lo temps de mon economat de Vila-seca. Començant a I2 de agost de I679 fins a Io juny I680, àpoca, 4 d'abril de I680.

8. Jordi Andreu Sugranyes, El Camp de Tarragona i el Priorat durant els segles XVIII $i$ XIX: les bases demogràfiques, agràries $i$ comercials de l'expansió setcentista, tesi doctoral, Universitat Autònoma de Barcelona, 1995, pp. 655-656.

9. AHAT, Parròquia de Sant Esteve de Vila-seca, manuals notarials de 19 de juny de I680 a 23 de maig de 1685, Obligacions preses per mi lo Pare de Predicador Fra Melchior Rubert, orde de Nostra Senyora de la Merçe Redenció dels Catius Christians. Corrent de este present añ de I685 desde el mes de juliol inclusive [...] i Manuale diversorum instrumentorum continuatum per me Gabrielem Monter, sancti teologica doctorem rectorem ac nottarium publicum presentis parrochialis ecclesiae Sancti Stephani Villasecca, Campi et Archidiocesis Tarracony, a die I7 januarii anno I688. 
Al marge de les partides de vi, s'han localitzat dos assentaments datats el Io de març de I688: l'un de cent quartans d'oli i l'altre de cinquanta quarteres de blat. L'oli l'havia adquirit a Joan Figuerola de Puigdelfí i el blat, procedent de Castellvell del Camp, l'havia negociat amb Pere Molné i Joan Sugranyes, membres del Consell de la vila.

\section{Etapa final: crisi i recuperació}

A finals dels anys vuitanta del segle Xvir els negocis al Camp de Tarragona els devien anar força bé; no tant els de Barcelona, on els creditors pressionaven. Les propietats tarragonines se'n van ressentir i van haver d'arrendar o vendre algunes finques. L'inici del segle XviıI va complicar encara més el futur de la companyia. La tardor del I70 es va signar la Gran Aliança de la Haia entre Anglaterra, Àustria i Holanda contra la dinastia borbònica i al maig de l'any següent, com se sap, ambdós bàndols s'enfrontaren en la Guerra de Successió. Felip V va ordenar l'embargament de mercaderies i propietats de comerciants anglesos i holandesos residents a Barcelona. Joan Kies va romandre pres a Tarragona i per a Arnold de Jäger es va decretar, el 28 d'octubre de I702, la seva expulsió i la de la família. Les institucions catalanes, Diputació i Consell de Cent, atès el que representava Jäger com a comerciant, van reclamar contra aquesta mesura i l'iı de juny de I703 van aconseguir anullar-la. Per afinitat a la causa austriacista, la repressió va afectar també personalitats com Narcís Feliu de la Penya, Amador Dalmau i el seu fill Sebastià, Pau Ignasi de Dalmases, Josep Faust de Potau i el seu pare, Cristòfol de Potau i Oller. ${ }^{\text {IO }}$

IO. Oliva Ricós, La generació de Feliu de la Penya, pp. I54-I55. Narcís Feliu de LA Peña, Anales de Cataluña y epílogo breve de los progresos, y famosos hechos de la nacion catalana [...] Divididos en tres tomos, Joseph Llopis, Barcelona, I709, pp. 505530. Joaquim Albareda Salvadó, «Política, economia i guerra», a A. Garcia Espuche, ed., Politica, economia, guerra. Barcelona I70o, Ajuntament de Barcelona, Barcelona, 2012, pp. 43-95. 
L'any 1702 la situació econòmica de Kies i Jäger es va complicar; i al començament del I703, sense liquiditat per poder retornar els crèdits que havien compromès, van fer fallida. La vinculació a la monarquia austriacista i les transaccions com a proveïdors els havien passat factura. El i70s la Reial Hisenda encara no havia pagat l'import pel gra amb què als anys noranta havia aprovisionat l'exèrcit. $\mathrm{El}$ total del deute es quantificava en 2II.807 lliures, 8 sous i 8 diners, que provenien dels censals, albarans, vals i lletres de canvi subscrits entre els anys I692 i 1702. Els negocis vinculats a contractes d'arrendament podien proporcionar beneficis importants, però eren arriscats; l'èxit depenia que el temps transcorregut entre el desemborsament per adquirir els subministraments i el pagament per part de l'entitat pública fos el menor possible. Calia planificar perfectament les operacions; si no, la manca de coordinació conduïa a la ruïna. La desfeta no només podia afectar la pròpia companyia: si l'empresa treballava amb capitals aliens, també arrossegava aquests inversors. ${ }^{\text {II }}$

El deute a curt termini, el 75\%, corresponia a albarans, lletres i vals, mentre que l'altre $25 \%$ es referia a operacions de pagament més indefinit, com els censals. Aquesta distribució podria ser la causa del desastre: mentre que la primera modalitat permetia als comerciants finançar les seves activitats, la segona era per adquirir béns immobles. Els fons provenien de la noblesa, dels eclesiàstics i de vídues. Sembla que el $80 \%$ del deute s'havia generat el I702, un any abans de produir-se la fallida. ${ }^{\mathrm{I2}}$

El 22 d'abril de 1703 es va signar la primera de les dues concòrdies entre Joan Kies i Arnold de Jäger i els creditors hipotecaris. El valor dels capitals corresponents a censals, canvis i altres deutes sumava 54.038 lliures, 6 sous i 3 diners, ${ }^{13} \mathrm{i}$ el de les pensions i els interessos era de $\mathrm{I} .570$

iI. Lobato Franco, Compañias y negocios, pp. i87 i I89. Carmen Sanz Ayán, Los banqueros de Carlos II, Servicio de publicaciones Universidad de Valladolid, Valladolid, I988, pp. 94-95.

I2. Ibidem, pp. I89-I9I.

13. En la relació desglossada de les anotacions, la suma és de 55.608 lliures, 6 sous i 3 diners, mentre que en la segona Concòrdia, del 9 de gener de 1705, és de 53.573 lliures, 16 sous i 3 diners. 
lliures. Els actius que posseïen, amb la possibilitat de ser venuts immediatament, no podien cobrir aquestes xifres. Un dels apunts assolia les 17.083 lliures, I6 sous i 3 diners, xifra que corresponia a la participació (5/II parts de 37.584 lliures, 7 sous i ro diners) que el I692 van demanar a censal per atendre la provisió de gra de l'exèrcit. La proposta realitzada pels deutors era respondre per un import de dos terços, «y no en més», dels crèdits respectius, tot i que la suma restant quedava hipotecada. Les propietats afectades inclö̈n les de Barcelona i la rodalia, les del Camp de Tarragona i qualsevol que poguessin tenir. Pel que fa a les possessions tarragonines, Joan Kies va haver de vendre o arrendar-ne algunes: el I69I va llogar trenta jornals annexos al castell de Vila-seca i el I706, al mateix indret, una part de l'hort. Aquestes operacions, tal com queda reflectit en les successives disposicions testamentàries, devien permetre salvar la part de patrimoni familiar situat en aquesta localitat. ${ }^{\mathrm{I}}$

El gener del I705 Kies i Jäger van pactar amb els creditors una segona concòrdia. Mentre que en la primera solament es preveien els drets dels creditors censalistes, canvistes i hipotecaris, en aquesta, després de reclamar un tracte igualitari, es reconeixien els dels quirològics. ${ }^{\text {I5 }}$ Entre altres obligacions, es comprometien a abonar una tercera part del deute amb la cessió dels béns immobles. Si malgrat les vendes no s'assolia la part convinguda, es lliurarien les mercaderies, els crèdits i els productes de l'activitat mercantil. El cobrament de les dues terceres parts que restaven s'ajornava un període de dotze anys, transcorregut el qual, si els creditors no havien cobrat, podien alienar la resta de béns mobles i

I4. Arxiu Històric de Protocols de Barcelona (AHPB), Vicenç Gavarró, « ${ }^{\circ}$ Transaccions (1689-1705)", núm. 49, Concordia entre Juan Kies y Arnoldo de Jagger y los acreedores censalistas e hipotecarios, 22 de abril de I703. Josep FÀBregas RoIG, "La compañía Kies-Jager, de la quiebra a la recuperación», a A. J. Rodríguez Hernández, J. Arroyo Vozmediano i J.A. Sánchez Belén, eds., Comercio, guerra y finanzas en una época de transición (siglos XVII-XVIII), Castilla Ediciones, Valladolid, 20I7, pp. 425-45I.

15. Els creditors quirològics no tenien garanties de cobrament. L'existència de diversos creditors d'aquesta tipologia significava que recuperarien els diners de manera proporcional; en canvi, els hipotecaris tenien preferència sobre la resta. 
immobles fins a satisfer el deute. Un últim apartat reflectia que si després d'haver venut tots els béns i pagat la tercera part als creditors quedaven diners, es destinarien a restituir el dot de l'esposa de Kies. No va ser fins al I743 que l'acord assolit pels representants dels comerciants holandesos i els seus creditors va quedar resolt definitivament. El control de la comptabilitat, que havia començat en signar-se la concòrdia - el 9 de gener de 1705 - , va estar actiu fins al I729, quan es van acabar de pagar algunes partides. El deute del Reial Patrimoni, per la provisió de gra del I690 i el I692, no es va saldar fins l'any I723. El balanç final reflectia un dèbit de 4.774 lliures; la suma que suposadament havien de pagar per liquidar el deute, incloent-hi les despeses dels apoderats, era de 98.586 lliures, quantitat molt allunyada de les 2 II.807 que devien. ${ }^{16}$

Joan Kies, enmig del desastre econòmic, moria a l'agost del $1708 \mathrm{i}$ Maria Àngela Sala, la seva esposa, ho feia al març següent. Del matrimoni sabem, almenys, el naixement de cinc filles i dos fills: Maria Isabel, Joan Francesc —-l'hereu_- Antoni, Anna, Raimunda, Maria Àngela i Gertrudis. En el moment de l'òbit dels pares eren menors d'edat i Josep Bover, prevere i canonge de la catedral de Tarragona, va ser-ne designat tutor. ${ }^{17}$

I6. AHPB, Francesc Durán, "Concòrdies (I697-I706)», Concordia de Kies y Jager ab sos acreedors hipotecaris y chirografaris, ff. 223-249. AHPB, Bartomeu Cervaró, "Manual, I742-I743», Balance de cuentas. Per al detall del concurs de creditors, vegeu Josep Fàbregas Roig, «La companyia Kies-Jager», pp. 425-45I.

I7. Josep FÀbregas Roig, "Joan Kies, un comerciant en el trànsit dels segles XVII al XVIII», Estudis d'Història Agrària, 26 (20I4), pp. 35-52. 


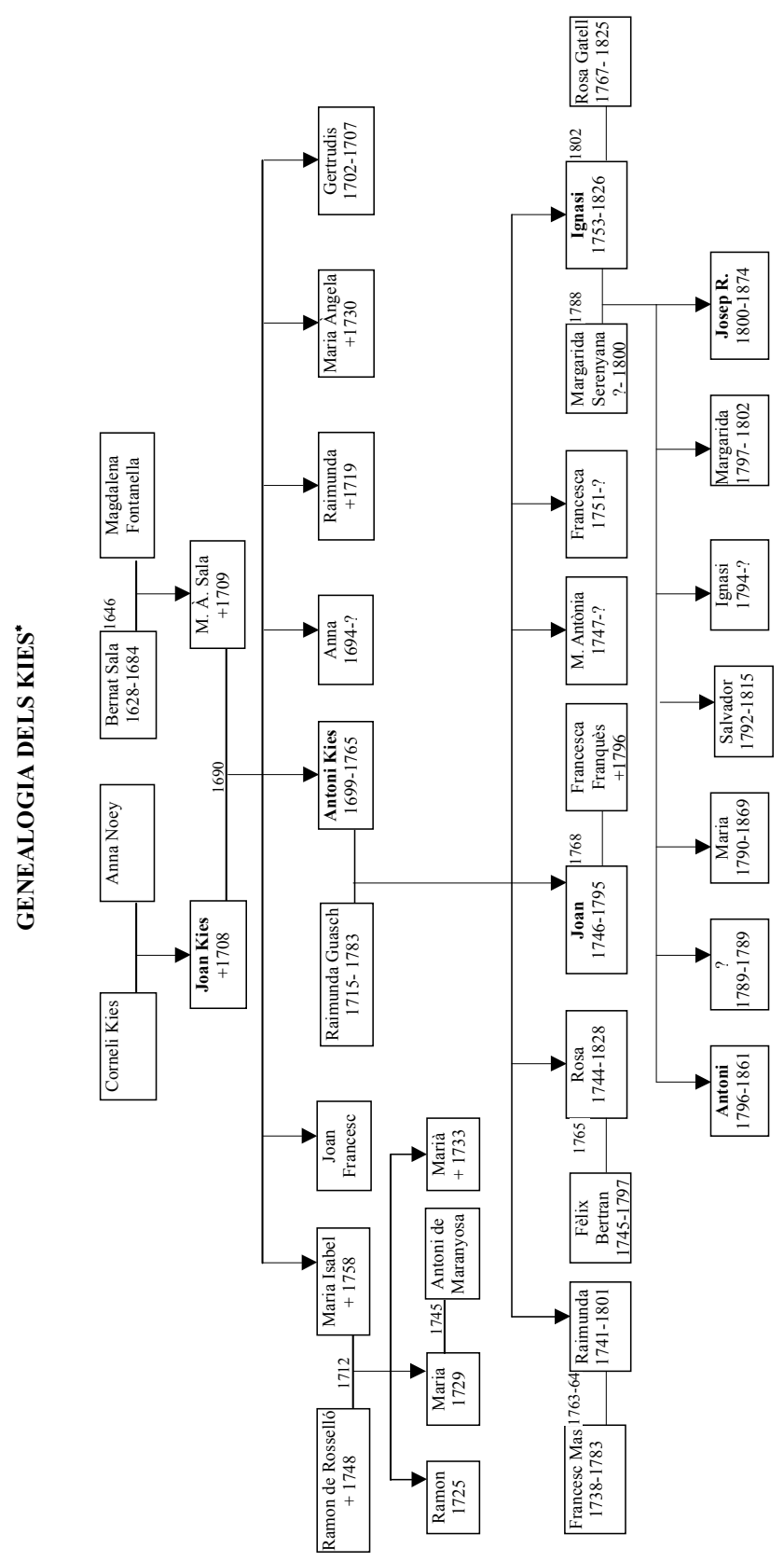

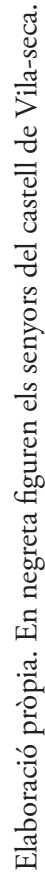

Pedralbes, 39 (20I9), I57-I9I, ISSN: O2II-9587, DOI: IO.344/PEDRALBES2OI9.39.6 


\section{Els Kies del segle XVIII}

Maria Isabel era la filla gran. Pel que fa a Joan Francesc —el primogènit-, sabem de la seva existència, però no disposem de dades ni del seu naixement ni de la seva defunció, la qual es va produir entre el is d'agost de 1703, data del testament del pare, i el 25 de maig de 1715, quan va sortir a la llum una valoració de les finques de Vila-seca en la qual la titularitat del castell és del seu germà Antoni. ${ }^{18}$ Anna havia nascut a Vila-seca, però també ignorem qualsevol fet de la seva vida, així com la data de l'òbit. Raimunda i Maria Àngela acabaren professant i van ser enterrades a Tarragona, al convent de Sant Domènec. Gertrudis va morir sent albat i les seves despulles foren inhumades al Collegi de la Companyia de Jesús de Tarragona. ${ }^{19}$ D'entre tots els germans, podem seguir la trajectòria de Maria Isabel i, sobretot, de l'hereu, Antoni Kies.

\section{a) Maria Isabel Kies Sala}

El 17 de gener de I7I2, a la catedral de Tarragona, Maria Isabel es va casar amb el noble vallenc Ramon de Rosselló i Castelló. L'oficiant va ser el canonge Josep Bover, al qual Joan Kies i Maria Àngela Sala, en el mo-

I8. Biblioteca de Catalunya (BC), Cadastre d'Aparici, valoracions dels béns dels habitants del terme de Vila-seca. Consultat el 8 de novembre de 2018 a: http://mdc.csuc. $\mathrm{cat} / \mathrm{cdm} /$ compoundobject/collection/cadastre/id/12507.

I9. AHPB, notari Tomàs Simon, II, «Testaments», testament de Joan Kies del I5 d'agost de 1703, ff. 230- 234. Arxiu Històric Arxidiocesà de Tarragona (AHAT), «Llibres del Tauler», de I719, f. I34; de I730, ff. I4O-I4I. Parròquia de Sant Esteve de Vila-seca, llibres I i II de baptismes, I/9/1566-4/I/I7I8, f. 352. Salvador J. RovirA Gómez, Rics i poderosos però no tant. La noblesa a Tarragona i comarca al segle XVIII, Cercle d'Estudis Històrics i Socials Guillem Oliver del Camp de Tarragona, Tarragona, 2000, p. II9. Josep Llor Tous, «L'església dels jesuïtes de Tarragona», a B. Bassegoda, J. Garriga i J. París, eds., L’època del Barroc i els Bonifas, Edicions de la Universitat de Barcelona, Barcelona, 2007, pp. 77-92. 
ment de la seva mort — com s'ha dit anteriorment—, havien designat tutor dels seus fills. ${ }^{20}$

Ramon, el I697, en la convocatòria adreçada a la noblesa, va intervenir en el setge de Barcelona al costat del virrei Jordi de Darmstadt. El seu pare, Rafael Joan, havia mort a finals dels anys setanta i, per part del nuvi, va ser la seva mare, Antònia Castelló, qui va pactar els capítols matrimonials. Ramon era l'hereu, tot i que Antònia es reservava el dret a l'usdefruit, amb el compromís d'acollir el nou matrimoni. Igualment es considerava que l'altre fill, Manuel de Castelló, rebria una casa situada a la plaça del Portal Nou de Valls, juntament amb dues mil lliures, tant si es casava com si prenia l'estat eclesiàstic, com sembla que era el desig matern. Per part de la núvia, van ser el tutor esmentat, Josep Bover, i Agustí de Figuerola, ambdós canonges de la catedral, els qui van oferir — seguint el llegat testamentari — un dot de tres mil lliures i dos baguls, un de roba blanca i l'altre amb teixits de llana, seda, or i plata. ${ }^{21}$ D'aquest matrimoni hem trobat una filla i dos fills: Maria, Ramon i Marià. El I745 Maria es va casar amb Antoni de Maranyosa de Moixó, un noble lleidatà. El fet que tres anys després morís el seu marit, degué influir en la decisió de traslladar-se a Lleida — acompanyant la seva filla_-, on va arrendar una casa propietat del convent de Sant Domènec. Era un habitatge d'una sola planta, format per nou espais: dormitori, cuina, dues habitacions, dos rebosts, dues cambres i un corral que, comparat amb els d'altres nobles lleidatans, podem qualificar de modest. Hem de tenir en compte que no disposava de rebedor, capella,

20. AHAT, parròquia de Santa Maria de la catedral, «Matrimonis, 3/1/169627/12/I7I6», f. I26v. Josep FÀBregas RoIG, "Joan Kies, un comerciant en el trànsit», pp. 35-52.

2I. Arxiu Comarcal de l'Alt Camp (ACAC), fons notarials, Joan Pau Cosidor, I705-I7I2, capítols matrimonials entre Ramon de Rosselló i Maria Isabel Kies Sala, ff. 238-246. Salvador J. Rovira Gómez, "Els nobles de Valls a l'època dels Austria», Historia et Documenta, 6 (2000), pp. I6I-I98. Idem, «Els nobles de Valls (segle XvIII)», Quaderns de Vilaniu, 6o (20II), pp. 59-85. Segons aquest autor, els Rosselló disposaven d'un ampli patrimoni agrari disseminat per diversos indrets del Camp de Tarragona, que tenien en arrendament, però això no va impedir que, acabada la Guerra de Successió, la família travessés dificultats econòmiques. 
sala, cotxera, ni magatzems. El mobiliari era l'imprescindible, amb armari i bagul, però sense bufet, calaixera, escriptori, ni llibreria. En canvi, l'aixovar s'adequava més al seu estatus. En els inventaris que ens presenta Josep M. Clarisó s'hi troben vuit cobrellits, vuit mantes, trenta fundes de coixí, seixanta-quatre llençols, trenta-una tovalloles i deu eixugamans. Els objectes de plata que posseïa pesaven més de trenta-dos kilograms i en destacaven: deu culleres, deu forquilles, sis ganivets, quatre canelobres, dues palmatòries, nou safates, quatre olles, calze, patena i altres recipients; en l'apartat de joies hi constaven un penjoll, una medalla i perles. Distribuïts per les diverses cambres hi havia tretze quadres i quinze pintures religioses, un santcrist, una imatge de la Mare de Déu i dos rosaris. No tenia llibres, només un missal. ${ }^{22}$

\section{b) Antoni Kies Sala, l'hereu}

Antoni Kies tenia nou anys quan va morir el seu pare i devia residir a Tarragona sota la custòdia de Josep Bover. ${ }^{23}$ Com a hereu, ja era titular de les propietats de Vila-seca. El i7is el castell, la fassina, la vinya, la hisenda i l'olivar estaven valorats en dotze mil lliures. ${ }^{24} \mathrm{~A}$ finals dels anys trenta del segle XVIII — no podem concretar la data - es va casar amb Raimunda Guasch Mañé, nascuda a Alcover. ${ }^{25}$ En els llibres sagramentals, Ignasi, el pare de la núvia, constava com a pagès. Els Guasch

22. Josep M. Clarisó Martí, «La economía de la nobleza de Lleida en el siglo xviII", tesi doctoral, Madrid, Universidad Nacional de Educación a Distancia, Facultad de Geografía e Historia, Departamento de Historia Moderna, 2016, p. 305. Del matrimoni, entre els anys I75I i I770, van néixer almenys onze fills, sis nois i cinc noies. Dels fills, quatre van seguir la carrera militar i dues noies van professar.

23. La seva germana Maria Isabel, en els capítols matrimonials, també constava com a domiciliada a Tarragona.

24. BC, Cadastre d'Aparici, valoracions dels béns dels habitants del terme de Vila-seca. Consultat el 8/II/20I8 a: http://mdc.csuc.cat/cdm/compoundobject/ collection/cadastre/id/I2507.

26. Malauradament, els llibres de matrimonis de la parròquia de l'Assumpció d'Alcover —on suposadament es devien casar- dels anys en què s'hauria pogut fer 
eren una família de llarga tradició; un text manuscrit d'un dels membres de la família indica l'adquisició al llarg del segle XVI de diverses peces de terra plantades d'oliveres i de vinya, concretament els anys I530, I537, I544, I565 i I603. En la primera operació, del 4 de febrer de I530, Joan Guasch, conegut com "del sol de la plaça», va comprar a Joan Fort una part de l'olivar a la partida de Vilar Sec per cinc lliures i deu sous, en un acte realitzat davant el vicari Lluís Ponsoda. ${ }^{26}$

Antoni i Raimunda van tenir quatre filles i dos fills: Raimunda, Rosa, Joan, Maria Antònia, Francesca i Ignasi, seguint aquest ordre. Raimunda va casar-se amb Francesc Mas, un pagès fill de botiguers, i fixaren la residència a Valls, a la casa familiar de la plaça del Blat; ${ }^{27}$ el matrimoni va tenir dues filles i quatre fills: Raimunda, Vicenç, Maria Antònia, Bernat, Joaquim i Francesc. ${ }^{28}$ Rosa va contraure matrimoni amb Fèlix Bertran, de Vila-seca, amb el qual va tenir vuit fills: Josep Antoni, Maria Rosa, Fèlix, Ignasi, un segon Fèlix — per defunció del primer-, Joaquim, Antònia i Francesc; tant Francesc com Fèlix eren familiars del Sant Ofici. ${ }^{29}$ Joan va ser l'hereu i el 1768 es va casar amb Francesca Franquès, filla d'una família noble d'Altafulla, però la relació no va funcionar i va acabar en divorci. No hi va haver descendència $i$ en el lideratge de la nissaga el va succeir Ignasi, el germà petit. Ignasi va contraure matrimoni dues vegades: la primera amb Margarida Serenyana, natural de Ripoll, i, quan aquesta va morir, amb Rosa Gatell, de

la celebració, no s'han conservat. Raimunda, la filla gran, va néixer el I74I, per la qual cosa podem considerar que les noces havien estat entre el I735 i el I740.

26. Arxiu Municipal d'Alcover (AMA), llibre de la família Guasch, segles XvIXVIII, reg. 230.

27. AHAT, Parròquia de Sant Joan Baptista de Valls, Llibreta de Combregans de la vila de Valls, 1764 .

28. AHAT, Parròquia de Sant Joan Baptista de Valls, Llibre de Batismes de la parroquial iglesia de san Joan Baptista de la vila de Valls, de l'i de gener de 1758 al 30 de desembre de 1768 , de l'i de gener de 1769 al 6 de setembre de 1779 i del 7 de setembre de 1779 al 30 de desembre de 1786 .

29. AHAT, Parròquia de Sant Esteve de Vila-seca, Llibre de desposoris, del 27 d'octubre de I760 al 29 de novembre de I80o; llibres iv i v de baptismes, del 6 de gener de 1767 al 3I de desembre de 1797. 
Tarragona; mentre que el primer enllaç va ser prolífic, amb set descendents, el segon no va donar fruits. ${ }^{30}$

D'Antònia i Francesca coneixem la data de naixement, però no la de defunció. El 1765 Francesca ja no constava en el testament del seu pare, i aleshores hauria tingut catorze anys. Antònia figura en el testament, però no s'ha pogut determinar si es va casar. Davant aquesta falta d'informació, una possibilitat seria que haguessin ingressat en algun convent.

L'activitat fonamental d'Antoni Kies va ser ocupar-se de les seves finques, la majoria ubicades a Vila-seca. Originàriament procedien de l'herència familiar $i$, sorprenentment, s'havien salvat del concurs de creditors produït com a conseqüència de la fallida de la companyia del seu pare. De tota manera, les dificultats econòmiques devien persistir força temps després de la mort dels progenitors. A finals de la dècada dels vint del segle XvirI li urgia obtenir liquiditat, fins al punt que el 20 de desembre de 1729 va vendre el dret d'un dia d'aigua per poder pagar el cadastre.

Més endavant va negociar diversos acords: a finals del 1744 va permutar amb Joan Salvadó, manescal de Vila-seca, un bocí de terra de set jornals, en part erm i en part plantat de mallol, situat al terme de Salou, a la partida del Gorg d'en Puig, ${ }^{31}$ per una finca de tres jornals amb garrofers ubicada a la Feredat, ${ }^{32}$ propietat de Salvadó..$^{33}$ En idèntica data ven a carta de gràcia al mateix Salvadó una peça de terra d'un jornal, poblada de garriga, i un corral derruït, per valor de cent lliures. La finca era al mateix indret que l'anterior i li pertanyia per llegat de la seva mare, Maria Àngela Sala. En els pactes s'estipulava que s'havia de reemborsar l'import de les millores realitzades al corral, sempre que

30. AHAT, Parròquia de Santa Maria de la Catedral, Matrimonis, Liber decimus tertius desponsatum in mence maii anni I800, I9 de març de 1802 .

3I. Ramon Amigó Anglès, Espigoladures onomàstiques, Publicacions de l'Abadia de Montserrat, Barcelona, 2005, p. IIO.

32. Ibidem, p. 139 .

33. AHT, Fons Notarial, Francesc Barreter, 1744, Permuta, 22 de desembre de 1744, ff. 396-398. La finca també provenia de l'herència de Maria Àngela Sala. 
Operacions d'Antoni Kies a Vila-seca per obtenir liquiditat ${ }^{34}$

\begin{tabular}{|c|c|c|c|}
\hline Data & Operació & Preu: Ll. S. D. & Observacions \\
\hline $7 / 6 / 1728$ & $\begin{array}{l}\text { Ven I, } 5 \text { jornals de terra campa } \\
\text { i olivera a la partida la Rabassa } \\
\text { i el dret a deu regades. }\end{array}$ & 1332 & $\begin{array}{l}\text { Comprador: } \\
\text { Joan Francesc } \\
\text { Coll, prevere i } \\
\text { beneficiat }\end{array}$ \\
\hline 9/II/I729 & $\begin{array}{l}\text { Compra un parell de bous. } \\
\text { Permet regar al venedor durant } \\
\text { quatre mesos fins a saldar el } \\
\text { deute. }\end{array}$ & 56 & $\begin{array}{l}\text { Venedor: Josep } \\
\text { Guardiola, pagès }\end{array}$ \\
\hline I5/I2/I729 & $\begin{array}{l}\text { Ven el dret a regar un dia a la } \\
\text { setmana durant un any. }\end{array}$ & 79 & $\begin{array}{l}\text { Arrendador: } \\
\text { Pere Guardiola, } \\
\text { pagès }\end{array}$ \\
\hline 20/I2/I729 & $\begin{array}{l}\text { Ven el dret a regar un dia a la } \\
\text { setmana durant un any. }\end{array}$ & 70 & $\begin{array}{l}\text { Arrendador: } \\
\text { Francesc Voltes, } \\
\text { comerciant }\end{array}$ \\
\hline
\end{tabular}

* AHAT, Parròquia de Sant Esteve de Vila-seca, Manual de contractes del reverent Casas de 1718 fins 1731, ff. 253, 298, 301, 302, 308 i 325.

s'acreditessin amb rebuts. El termini de què disposava Kies per recuperar la propietat era de quatre anys $\mathrm{i}$, en cas de fer-ho, si volia vendre-la novament, Salvadó tindria dret de tempteig. ${ }^{35}$ El 1752 va vendre també a carta de gràcia a Josep Cabrer, ferrer de Vila-seca, un bocí de dotze jornals sembrat d'ordi i blat i algunes oliveres, situat a la partida del Pontet, juntament amb el dret de tres dies d'aigua setmanals de la mina d'aquest nom, des del dimecres a les sis de la tarda fins al dissabte a la mateixa hora. Com que la finca estava en producció, el venedor es reservava el dret a recollir la propera collita, i es faria de la mateixa manera en el supòsit que Kies volgués recuperar-la. També van acor-

34. AHAT, Parròquia de Sant Esteve de Vila-seca, Manual de contractes del reverent Casas de 1718 fins 1731, ff. 253, 289, 301, 302, 309 i 325.

35. AHT, Fons Notarial, Francesc Barreter, 1744, Venda, 22 de desembre de 1744, ff. 405-407. La seva mare l'hi havia llegat, segons el que constava en el testament, avui desaparegut, redactat per Ramon Permini el 28 de març de 1709 . 
dar que el venedor no pogués disposar de la terra mentre el comprador no hagués plegat les properes collites d'hivern i d'estiu i, si ho feia abans de ser sembrada, passades les dues collites esmentades li havia de compensar els treballs realitzats. L'import de l'operació va ser de cinc-centes seixanta-cinc lliures, incloent-hi el lluïsme, que era de quinze lliures. ${ }^{36}$

L'in d'octubre de I762, en la declaració del capbreu, realitzada al castell de Vila-seca, confessava la possessió de:

[...] tota aquella heretat gran ab son Castell y Casa, y hort a ella contiguo, nomenat antigament lo Castell de Mosen Saportella, despues de mosen Valls, despues de mosen Jardí y vuy del Consul de Olanda, situada en lo terme de Vilaseca, y fora, y prop los Murs de ella, en la partida dita la Iglesia Vella, detinguda de cinquanta tres jornals [...], pel mig de la qual passa lo camí publich, eo la carretera que va de la present Vila a la de Reus; en la qual heretat va comprés un olivar, dit lo olivar novell de pertinencias de ella, detinguda de vuit jornals [...], altre olivar dit lo olivaret y no menos una pessa de terra detinguda de tres jornals [...], junt ab la aygua que ve del mas den Riba, ab sa sequia, antoxás y Bassa, nomenada antiguament del Castell qual bassa està construhida entre la terra de Ramon Pons y la terra de Joseph Mariner. [...] Y se tenen per la mensa Archiepiscopal de Tarragona y tots son Domini y alou a cens de vint lliuras, nou sous y deu diners Bars pagadors tots anys, ço es las vint lliuras lo dia de Sant Feliu y los nou sous y deu diners lo dia de Nadal [...]. ${ }^{37}$

En la declaració només es feia referència a les finques —espai físic - com a reconeixement de la senyoria eclesiàstica que exercia el domini en el territori, però no s'esmentaven altres activitats, com la producció d'aiguardent realitzada en dependències annexes. Antoni Kies va ser una persona inquieta a tenir cura del seu patrimoni i po-

36. AHT, Fons Notarial, Carlos Clavería, I752, Venda, 28 d'abril de I752, ff. II4II6.

37. AHAT, Arquebisbe, Patrimoni de la Mitra, còpia del capbreu de Vila-seca i Salou de la Pineda i la Plana, rebut en poder de Joan Antoni Russa, notari públic de Tarragona els anys 1762 i I763, f. 204. 
dem deduir que si es va veure abocat a realitzar aquestes vendes va ser perquè se li van plantejar altres negocis i aquesta era la millor solució per atendre'ls.

El Io de juny de 1765 va morir Antoni Kies, després de confessar-se, combregar i rebre la unció dels malalts. En el testament demanava ser inhumat a l'església de Vila-seca, a la sepultura d'en Torrell. Se li va fer enterrament general, amb novena i cap d'any amb toc doble, diaques $\mathrm{i}$ dotze atxes de cera groga, i van assistir-hi disset sacerdots: rector, vicari, dos beneficiats, mossèn Sauné — tots residents a Vila-seca - i dotze monjos, sis franciscans del convent de Reus i sis caputxins del de Tarragona. Per a les exèquies esmentades va deixar setanta lliures barceloneses, i els diners sobrants, en cas d'haver-n'hi, s'havien de dedicar a misses resades. Per a la salvació de la seva ànima s'havien de celebrar cent vint misses, seixanta al convent dels caputxins de Tarragona i seixanta al dels franciscans d'Alcover, a raó de cinc sous per missa. Just una setmana abans havia fet testament i designava com a marmessors el seu sogre, Ignasi Guasch, el seu gendre, Francesc Mas, i el seu consogre, Josep Bertran, tots familiars del Sant Ofici a Alcover, Vila-seca i Valls, respectivament.

Pel que fa al repartiment dels béns, a la seva filla Raimunda - casada amb Francesc Mas - li va atorgar quatre-centes lliures barceloneses com a legítima paterna; a Rosa n'hi va concedir mil quatre-centes, que l'hereu abonaria en dos terminis: un el dia del casament i l'altre al cap d'un any. Aquesta quantitat, com s'aprecia en els capítols matrimonials, establerts amb Fèlix Bertran, incloïa l'import del dot en cas de matrimoni. A Maria Antònia li corresponien també mil quatre-centes lliures amb els mateixos termes que Rosa, de les quals en podria conservar tres-centes, en cas que morissin els fills que pogués tenir o no arribessin a l'edat de testar. A Ignasi li va atorgar dues mil lliures per a quan es casés, però si professava només podria disposar de cinc-centes i la resta la recuperaria l'hereu. Raimunda, la seva esposa, quedava com a usufructuària a canvi de donar aixopluc als descendents, sempre que no es tornés a casar. Declarava Joan hereu universal, amb la condició que havia de contraure matrimoni, però si malgrat fer-ho no tenia fills o en tenia i no arribaven a l'edat de fer testament, solament podria gaudir de 
mil lliures, Ignasi esdevindria l'hereu i si es donava el mateix supòsit en ell, es continuaria per línia femenina seguint l'ordre de naixement, és a dir, Raimunda, Rosa i Maria Antònia, successivament. ${ }^{38}$

Des del capbreu del I762, a l'entorn dels Kies s'havien produït alguns canvis, primer la mort d'Antoni Kies, després la d'Ignasi Guasch - el pare de Raimunda_- amb la qual cosa el patrimoni es va engrandir amb les finques d'Alcover. També va tenir lloc el matrimoni de l'hereu amb Francesca Franquès, d'Altafulla.

El 30 d'octubre de 1782 Raimunda Guasch, en trobar-se malalta, va fer testament: confirmava Joan Kies com a hereu universal i en cas que no tingués successió, només disposaria de dues-centes dobles. L'ordre que es va seguir a continuació va ser el mateix que a les últimes voluntats del seu pare. ${ }^{39}$

\section{c) Joan Kies Guasch}

En finalitzar la situació d'usdefruit de què gaudia Raimunda Guasch i revertir en ell l'herència, el 8 de març de 1783 Joan Kies va fer inventari dels béns. La primera propietat anotada fou el castell de Vila-seca, que descriu amb una torre i envoltat per una tanca dins la qual hi havia mig jornal de terra de cultiu, amb les casetes d'eines corresponents i les «oficines» d'aiguardent, que contenien dues olles de quatre càrregues i mitja cada una, amb una bassa gran i un cup amb cabuda per a dues-centes càrregues de verema. ${ }^{40}$ En el document afegeix —-segurament per valorar els beneficis que poguessin correspondre a la seva esposa Francesca per raó de matrimoni- que les fassines i olles d'aiguardent,

38. AHT, Fons Notarial, Francesc Barreter, Testament, 3 de juny de 1765, ff. 229232. AHAT, Parròquia de Sant Esteve de Vila-seca, Llibre II d'òbits, 2/1/1737-25/12/1798, f. I23.

39. Arxiu de la Corona d'Aragó (ACA), Real Audiencia, «Pleitos Civiles», núm. 631, Testament de Raimunda Kies Guasch, 30 d'octubre de 1782.

40. Antoni Maria Alcover i Francesc de Borja Moll, Diccionari català-valenciàbalear, IEC, Barcelona, 2002. La carga de verema al Camp de Tarragona era de I2 arroves. 
la construcció de les teulades, l'aqüeducte i un celler amb dos cups de sis-centes càrregues de verema, es van fer amb diners propis i del dot aportat per ella. Dins el castell hi havia el mobiliari i els estris habituals. Resulta remarcable la presència d'un cofre gran de noguer que encara contenia diferents llibres i papers del negoci del seu avi, el cònsol d'Holanda. També hi va anotar sis coberts de plata mitjans usats i quatre ganivets amb mànec de plata.

\section{Relació de finques a Vila-seca}

\begin{tabular}{|l|c|l|}
\hline \multicolumn{1}{|c|}{ Finca o partida } & Jornals & \multicolumn{1}{c|}{ Conreu } \\
\hline Castell de Vila-seca & 0,5 & Cultiu sense determinar \\
\hline Església vella $a^{41}$ & 27 & 3.0oo ceps i arbres \\
\hline Església vella & 28 & Olivers arbequins i I.Ioo ceps \\
\hline Olivaret, església vella & 8 & Vinya, olivers arbequins i garrofers \\
\hline Església vella & $1 / 2$ quartót & Moreres \\
\hline Total & $\begin{array}{l}\text { 63,5 jornals } \\
\text { i 1 } 12 \text { quartó. }\end{array}$ & \\
\hline
\end{tabular}

En vida d'Anton Kies la majoria d'aquestes finques eren terres de conreu. En heretar-les Joan, també amb diners propis i del dot i amb la idea de millorar-les, va substituir els cultius existents —en algun cas, d'horta - per vinya i arbrat. Aquests canvis van significar alçar parets de pedra i fang, arrebossades amb argamassa, i construir mines d'aigua, com la del Pontet. En l'inventari, a fi que no hi hagués dubtes de la seva gestió del patrimoni familiar, després de descriure cada propietat feia esment repetidament a les reformes que hi havia introduït.

4I. En aquest indret hi havia la mina de la font de l'Alba. La finca era vora el camí ral que portava a la Canonja; una part tocava amb la carretera de Tarragona i una altra, amb la carretera que conduïa a la Selva. En vida d'Anton Kies només hi havia conreus i Joan es va encarregar de plantar-hi arbres

42. Antoni Maria Alcover i Francesc de Borja Moll, Diccionari català-valencià-balear, Quartó: «Mesura agrària de valor variable segons les comarques». Al Pla del Llobregat, Igualada, Mataró, Penedès i Vilanova i la Geltrú, és la quarta part d'una mujada, equivalent a 506,25 canes quadrades o a 12,24 àrees. 


\section{Relació de censals}

\begin{tabular}{|l|c|c|c|}
\hline \multicolumn{1}{|c|}{ Nom i cognoms } & $\begin{array}{c}\text { Data de } \\
\text { venciment }\end{array}$ & $\begin{array}{c}\text { Capital/ } \\
\text { lliures }\end{array}$ & $\begin{array}{c}\text { Pensió/ } \\
\text { lliures }\end{array}$ \\
\hline Josep Solé & I de desembre & 300 & 9 \\
\hline Pau i Maria Saritjol & I4 d'agost & IOO & 3 \\
\hline Tecla Cortiella & - & 200 & 6 \\
\hline Hilari Vives & I2 de setembre & 50 & I,5 \\
\hline Total & & 650 & I9,5 \\
\hline
\end{tabular}

Manifestava també un possible censal que el seu pare tenia contra el comú de Mataró sobre el dot de la seva àvia Maria Àngela Sala i que, quan es confirmés, també inventariaria, junt amb altres béns que pogués trobar posteriorment. ${ }^{43}$

La seva mare havia mort a Alcover el I6 de gener de 1783 i en el llistat de finques hi havia les següents:

Finques d'Alcover ${ }^{44}$

\begin{tabular}{|c|c|c|c|}
\hline Finca/partida & $\begin{array}{c}\text { Sup./ } \\
\text { Jornals }\end{array}$ & Conreu & Observacions \\
\hline Casa familiar & - & - & Cl Abadia, "Costeta» \\
\hline
\end{tabular}

(Continua a la pàgina següent)

43. ACA, Real Audiencia, «Pleitos Civiles», núm. 63I, Inventari dels béns de D. Anton Quies del Castell de Vila-seca pres per D. Joan Quies dels béns de son pare, per mort de sa mare, 8 de març de I783, ff. I29-I35.

44. Moisès Selfa Sastre, Onomàstica d'Alcover, Societat d'Onomàstica / Institut Cartogràfic de Catalunya, Barcelona, 2008, pp. 46, I6I, I65, I57, II8, I69, 75, 82 i 83, respectivament. Argiles: partida, de bona extensió, de secà, situada entre la carretera de Montblanc i la de Valls, al nord-est del terme d'Alcover; documentada des del segle XviII. Serra: situada en els termes d'Alcover i Valls, al llarg de la carretera de Picamoixons, entre el pont de Goi i les Quatre Carreteres. Tombassa: partida a tocar amb la dels Segalers. Segalers: partida ubicada entre el Serradalt i les Argiles. Marxant: partida travessada per la carretera de Vilallonga. Vilar Sec: s'estén vora la carretera de Vilallonga, ben a prop de les hortes d'Alcover. Cogoll: és el punt alt d'un turó a tocar del terme de Vilallonga, al sud del d'Alcover. Cogollet: partida situada entre les del Cogoll i del Burguet, al sud del terme d'Alcover. Dimecres, Dijous, Dissabte: terres de regadiu, de l'horta d'Alcover, vora el nucli urbà. 


\begin{tabular}{|l|c|l|l|}
\hline Finca/partida & $\begin{array}{c}\text { Sup./ } \\
\text { Jornals }\end{array}$ & \multicolumn{1}{|c|}{ Conreu } & Observacions \\
\hline Casa i corral & - & - & C/ Abadia, «Costeta» \\
\hline Sitjar & 0,5 & Horta & \\
\hline Argiles & 8 & Sembradura i vinya & \\
\hline Benilau & 2,5 & Vinya i garrofers & \\
\hline Serra & 20 & Horta, garriga i garrofers & Amb casa \\
\hline Serra & 2 & Horta & \\
\hline Tombassa & I,5 & Oliveres & \\
\hline Segalers & I & Vinya, garrofers i garriga & \\
\hline Marxant & 25 & Vinya, garrofers i garriga & \\
\hline Vilar Sec & I4 & Vinya i oliveres & \\
\hline Cogoll & 3 & Vinya & \\
\hline Cogollet & 2,5 & Vinya & \\
\hline Dimecres & I & Horta & \\
\hline Dijous & 2 & Horta & \\
\hline Dijous & 2 & Horta & \\
\hline Dijous & 2 & Horta & \\
\hline Dijous & I,5 & Horta & \\
\hline Dissabte & 0,5 & Horta & \\
\hline Rec & I,5 & Horta & \\
\hline Total & 90,5 & & \\
\hline & & & \\
\hline
\end{tabular}

El contingut que hi havia a la casa pairal, igual que en el cas dels béns paterns, era compost pels estris que podríem trobar en un immoble qualsevol de la ruralia. De cap manera no denotava la grandesa de la família. Constituïen el parament de la llar objectes gairebé tots usats i alguns fins i tot en mal estat. Com a excepció s'hi van trobar alguns coberts de plata (vuit forquilles i cinc culleres), trenta-dos plats grans i onze escudelles de pisa fina, a més de tretze gots de cristall. ${ }^{45}$

45. ACA, Real Audiencia, «Pleitos Civiles», núm. 631, Inventari pres per D. Joan Quies per mort de Da Raymunda Quies, sa mare, dels béns de esta en Alcover, 20 de gener de I783, ff. I35-I42. Salvador J. Rovira Gómez, Els nobles del Baix Camp (segle XIX), Associació d'Estudis Reusencs, Reus, 2008, pp. I39-I4I. 
El 2I d'agost de I79I la comunitat del rector i els preveres d'Alcover va capbrevar; Joan Kies hi declarava dues vinyes, una de dos jornals i l'altra de mig. La primera es trobava a la partida del Mas d'en Grau, al camí de Tarragona, i el dia de Sant Nicolau pagava un cens de dos sous i dos diners. La segona era a la partida de Segalers, amb un cens de sis diners que s'havia d'abonar el i8 d'octubre. ${ }^{46}$

Podem assegurar que la gestió de Joan Kies, del seu patrimoni, no va ser un èxit, com demostren alguns deutes contrets en els darrers anys de la seva vida.

El 29 de desembre de 1787 confessava un deute de I.450 lliures a Joan Molins, comerciant de Reus; a canvi, li havia de lliurar aiguardent de primera qualitat. ${ }^{47} \mathrm{~A}$ finals del 1790 Gregorio Gayá, apoderat i arrendatari dels delmes pertanyents a Ramon Foguet, prevere i ardiaca de Vila-seca, s'havia presentat al castell per informar-lo que tenia prou poders per cobrar les taxes; eren les corresponents a faves i mongetes, que encara no havia pagat. Davant de dos testimonis va declarar que es negava a abonar-les. ${ }^{48}$

A mitjan abril de I79I, Francesc i Geroni Massó, pare i fill, mestres cirurgians d'Ulldemolins, havien cobrat de Joan Kies la quantitat de I.540 lliures barceloneses, import d'una casa amb hort situada a Vila-seca, al raval de l'església vella, que li havien venut el to de febrer de 1779. En realitat el preu de la finca era de I.I6o lliures i les 380 restants corresponien als interessos generats durant els dotze anys que s'havia allargat el pagament, segons una sentència de l'any anterior de la Reial Audiència de Catalunya. ${ }^{49}$ En relació amb aquesta operació, el juliol del I790 Joan Kies abonava a Tecla Subirà i al seu fill Francesc Vilella 262 lliures en concepte de "paga, lluïció i quitació» d'un censal mort de

46. AHT, Fons Notarial, Antoni Aloy, capbreu de la Reial Comunitat Vila d'Alcover, I79I, f. 55 .

47. AHT, Registre d'Hipoteques de Tarragona, I788, f. 55, dèbit.

48. AHT, Fons Notarial, Josep Guardiola Voltes, I790, requeriment, Josep Guardiola, 2 de desembre de 1790.

49. AHT, Fons Notarial, Josep Guardiola Voltes, I79I, àpoca de Francesc i Geroni Massó a Joan Kies, I4 d'abril de I79I, f. I39. 
200 lliures de capital i una pensió anual de sis lliures; les altres 62 lliures corresponien als pagaments vençuts de deu anys i quatre mesos, i el censal formava part de la transacció anterior. ${ }^{50}$

Les tres reclamacions següents, la de Bonaventura Bofarull, la de la casa Milà i Fabregat i la de la Compañía de los Cinco Gremios Mayores de Madrid, es van veure conjuntament en un plet a la Reial Audiència. A Bonaventura Bofarull, ${ }^{\text {sI }}$ segons una escriptura de finals de desembre de $\mathbf{1 7 9 3}$, li reconeixia un deute de 2.200 lliures; la devolució, a tot tardar, s'havia de fer el 3I de juny de l'any següent mitjançant una partida d'ordi de bona qualitat. El I6 de setembre de I794, com que encara no havia recuperat el préstec i Joan Kies esquivava les reclamacions, Bonaventura li va enviar un requeriment per recordar-l'hi. Com a resposta, Kies va al-legar que no havia estat un préstec gratuït, sinó que després de signar la escriptura esmentada, havia lliurat algunes mercaderies amb uns valors tan fora de lloc que, venudes a preus regulars —incloent-hi els bocois que es va quedar Bonaventura a un preu de sis lliures cada un però que en el moment del lliurament es van taxar a vuit-, va quedar perjudicat en 942 lliures, 8 sous i 5 diners. També reconeixia que li faltava lliurar articles per un valor de 200 lliures i acceptava que, en cas de no fer-ho, es mantingués el deute de 2.500 lliures; afegia que si Bofarull pretenia que, a canvi d'aquest import, li lliurés l'ordi al preu vigent el 30 de juny de 1794 , li ocasionaria una pèrdua considerable, al mateix temps que Bofarull tindria uns guanys excepcionals. Com que - segons ell — no volia perjudicar-lo, dels beneficis obtinguts de les mercaderies que li va proporcionar —en lloc del préstec_-, li va oferir pagar un $6 \%$ més del seu valor, però si no ho acceptava i insistia en la reclamació, per evitar publicitat indesitjable i costos d'execució li oferia una finca plantada de vinya i garriga de 25 jornals situada a la partida Mar-

50. AHT, Fons Notarial, Josep Guardiola Voltes, I790, àpoca de Tecla Subirà i Francesc Vilella a Joan Kies, I de juliol de I790.

5I. Els Bofarull van ser una rellevant nissaga de comerciants reusencs del segle XVIII, una part de la qual havia assolit títols de noblesa. En aquest moment, Bonaventura era "contador de Fragata de la Real Armada y Subdelegado de Marina" de Reus, Vila-seca i el port de Salou. 
xant, a Alcover, valorada en unes 5.000 lliures, que es podrien obtenir subhastant-la. El 22 d'octubre confirmava un deute de I.06o lliures; com que no podia saldar-les, Bofarull va acceptar ajornar el cobrament fins al novembre de l'any següent. Kies li concedia dret preferent i en cas de vendre algun producte es comprometia a abonar la quantitat endeutada, malgrat que el termini no s'hagués exhaurit. ${ }^{52}$

El 23 de maig de 1794 escripturava un préstec de 600 lliures catalanes amb la companyia de Milà i Fabregat, comerciants reusencs. Retornaria l'import amb una partida d'aiguardent, prova d'holanda, al preu assenyalat al mercat de Reus el Io de novembre; cinc dies després el lliuraria sense costos. La transacció no es va fer efectiva i el i8 de novembre el notari Gregorio Alonso de Valdés, a petició dels demandants, el va instar a lliurar l'aiguardent corresponent; el preu s'havia fixat en I9 lliures i 5 sous la càrrega. Kies reconeixia el deute i justificava el retard dient que havia tingut tres execucions. ${ }^{53}$

Finalment, el I3 de març de 1795 Sebastián Martín, apoderat de Miguel Mancheno i Francisco Martínez de Negrete, directors de la casa de comerç Cinco Gremios Mayores de Madrid —residents a Reus_-, exposava a Ramon Texidor, ${ }^{54}$ doctor en drets i tinent de corregidor a Tarragona, que el 8 de maig de 1794 Kies havia reconegut un deute de 4.293 lliures, I5 sous i 8 diners, quantitat que devia ser destinada a obres i conreus de les seves finques. Kies havia de respondre amb diners o aiguardent per tot el mes de novembre, per la qual cosa s'hipotecava tota la collita de vi i aiguardent amb preferència a qualsevol altre creditor.

52. AHT, Fons Notarial, José Alonso de Valdés, I793, reconeixement de deute, 24 de desembre de 1793; José Alonso de Valdés, I794, requeriment de deute, I6 de setembre de 1794, i resposta del I7 de setembre de 1794; José Guardiola Voltas, I794, escriptura de debitori, 22 d'octubre de 1794, ff. 326-328. ACA, Real Audiencia, «Pleitos Civiles», núm. 63I.

53. AHT, Fons Notarial, Josep Alonso de Valdés, 1794, reconeixement de deute, 23 de maig de I794. També a ACA, Real Audiencia, «Pleitos Civiles», núm. 63I.

54. Rafael Cerro Nargánez, «La nómina de los alcaldes mayores de Cataluña (I717-I834)", Ivs Fvgit, 8-9 (1999-2000), pp. 45-74. Ramon Texidor va ocupar el càrrec a Tarragona entre els anys I793 i I797. Anteriorment ho havia estat a Granollers (I773I776), Montblanc (I776-I780) i Balaguer (I784-I790). 
Joan Kies va morir el 3I de gener de 1795 sense haver retornat els diners, de manera que els demandants van orientar les reclamacions a Ignasi, designat hereu pel seu germà en el testament del 29 de gener, i a la seva esposa, Margarida Serenyana. ${ }^{55}$

Es va haver d'esperar fins l'i de febrer de 1799 perquè el magistrat Antonio Pellicer de la Torre dictés sentència:

El pago de los créditos y cantidades que piden la Factoría de los Cinco Gremios Mayores de Madrid, D. Buenaventura Bofarull y Francisco Fabregat en el nombre que sigue a esta causa, no viene a cargo de los bienes de fideicomiso de la casa de Kies, sí de los bienes libres del difunto D. Juan Kies que contrajo aquellas deudas; y que en su conseqüencia impone a dichos actores silencio perpetuo en sus respectivas demandas en cuanto las dirigen contra los consortes D. Ignacio y Da. Margarita Kies y Sereñana y sus bienes vinculados, reservandoles como se les reserva su derecho para que en otro juicio la repitan contra los bienes libres del enunciado D. Juan Kies. ${ }^{56}$

Segons el veredicte, la reclamació no es va argumentar adequadament: la demanda havia de ser sobre els béns personals de Joan Kies, no sobre els sotmesos a fideïcomís. En el transcurs del litigi, els creditors van intentar demostrar les millores que amb els diners prestats havia fet Joan Kies a les seves finques i conreus, mentre que els demandats no solament negaven aquestes millores, sinó que fins i tot asseguraven que les propietats havien perdut valor. Per altra banda, en una escriptura del 5 de desembre de 1787 - molt abans de generar els deutes - es demostrava que Kies havia fet donació a Margarida Serenyana, posteriorment esposa del seu germà, «no solo de todos los derechos que en calidad de heredero gravado de sus padres le pudiesen pertenecer en la herencia de ellos, sino también de las mejoras hechas en sus heredades y bienes y de qualesquiera otras cosas que le correspondiessen $» .57$

55. ACA, Real Audiencia, «Pleitos Civiles», núm. 63I, f. 38.

56. Ibidem, f. 248 i 249.

57. Ibidem, f. I75. 
Els demandants no van quedar satisfets i van recórrer la sentència. El 27 de gener de 1803 es va citar a declarar Benito Sacco, comerciant maltès, per continuar el litigi..$^{58}$

La vida personal de Joan Kies tampoc no va resultar reeixida. El I768 s'havia casat amb Francesca Franquès, tia del reconegut científic Antoni Martí i Franquès, de la qual es va divorciar. ${ }^{59}$ Els mateixos lletrats representants d'Ignasi Kies, per defensar-lo en el plet, al.legaven que resultava inversemblant que una persona tan malgastadora pogués millorar cap propietat. ${ }^{60}$

\section{d) Ignasi Kies Guasch, el darrer Kies del segle XVIII}

Ignasi Kies, just després d'haver-se convertit en cap de la nissaga, per una banda va haver de resoldre la reclamació del dot que Francesca Franquès, esposa de Joan Kies, havia aportat al matrimoni i dels possibles béns que li poguessin correspondre pel temps que va estar casada, i per l'altra va haver de reconduir la situació econòmica de la família.

Pel que fa als drets de Francesca Franquès arran de la mort del seu marit, aquesta es va reunir amb Ignasi per resoldre el tema amistosament. En les negociacions també hi va intervenir Antoni de Martí i Franquès, nebot de Francesca i hereu. Francesca va renunciar a la part que li podia correspondre dels béns de guanys i les millores patrimonials, però pel que fa a les I0.00o lliures de dot, com que coneixia la delicada situació econòmica que afrontava el seu cunyat, va acceptar demorar-ne la devolució. En principi les podia conservar a canvi d'una pensió anual de 475 lliures barceloneses, en or i plata, a raó de 158 lliures, 6 sous i 8 diners cada quatre mesos. Les I0.00o lliures podria restituir-les en lliu-

58. Ibidem, f. s/n.

59. Salvador J. Rovira Gómez, Rics i poderosos, p. i20. Francesca Franquès i Gatell era filla de Ramon Franquès, hisendat i comerciant d'Altafulla; Maria, la seva germana, s'havia casat el 1749 amb Antoni Martí i Gatell, pare del científic Antoni Martí i Franquès.

6o. ACA, Real Audiencia, «Pleitos Civiles», núm. 63I, ff. 222 i 223. 
raments no inferiors a $2.000 \mathrm{i}$ proporcionalment es restarien de la pensió anual de les 475. En el supòsit que Francesca morís abans de quatre anys, a comptar des del moment de la signatura del document, Antoni Martí podria reclamar el dot o la part no retornada i tindria dret a percebre la pensió assignada a la seva tia, en funció de les quantitats abonades. De les 200 dobles de creix que Joan Kies va oferir a Francesca, podia gaudir de la meitat i si no en disposava, revertirien en els seus hereus. El pacte no va durar perquè Francesca va morir el mateix any, la qual cosa — amb el retorn del dot pel mig — va obrir un nou capítol en les relacions entre Ignasi Kies i Antoni Martí. ${ }^{61}$

La delicada situació econòmica dels Kies es va posar de manifest perquè Ignasi va haver de reduir el seu patrimoni. Durant els anys I795 i 1796 va signar trenta-set escriptures de venda; les finques, que envoltaven el castell de Vila-seca, van passar a mans de diversos propietaris per construir-hi habitatges.

L'import de les vendes va assolir les 6.860 lliures. La manca de numerari dels compradors va fer que la majoria haguessin de crear censals; només la quarta part van pagar al comptat. La suma de les pensions va arribar a les 552 lliures. $^{62}$

6I. Ibidem, conveni entre Ignasi Kies i Francesca Franquès, 29 de gener de 1796, ff. 198-205.

62. AHT, Fons Notarial, Josep Guardiola Voltes, Salvador Girona Rovira, manuals de 1795 i 1796. 


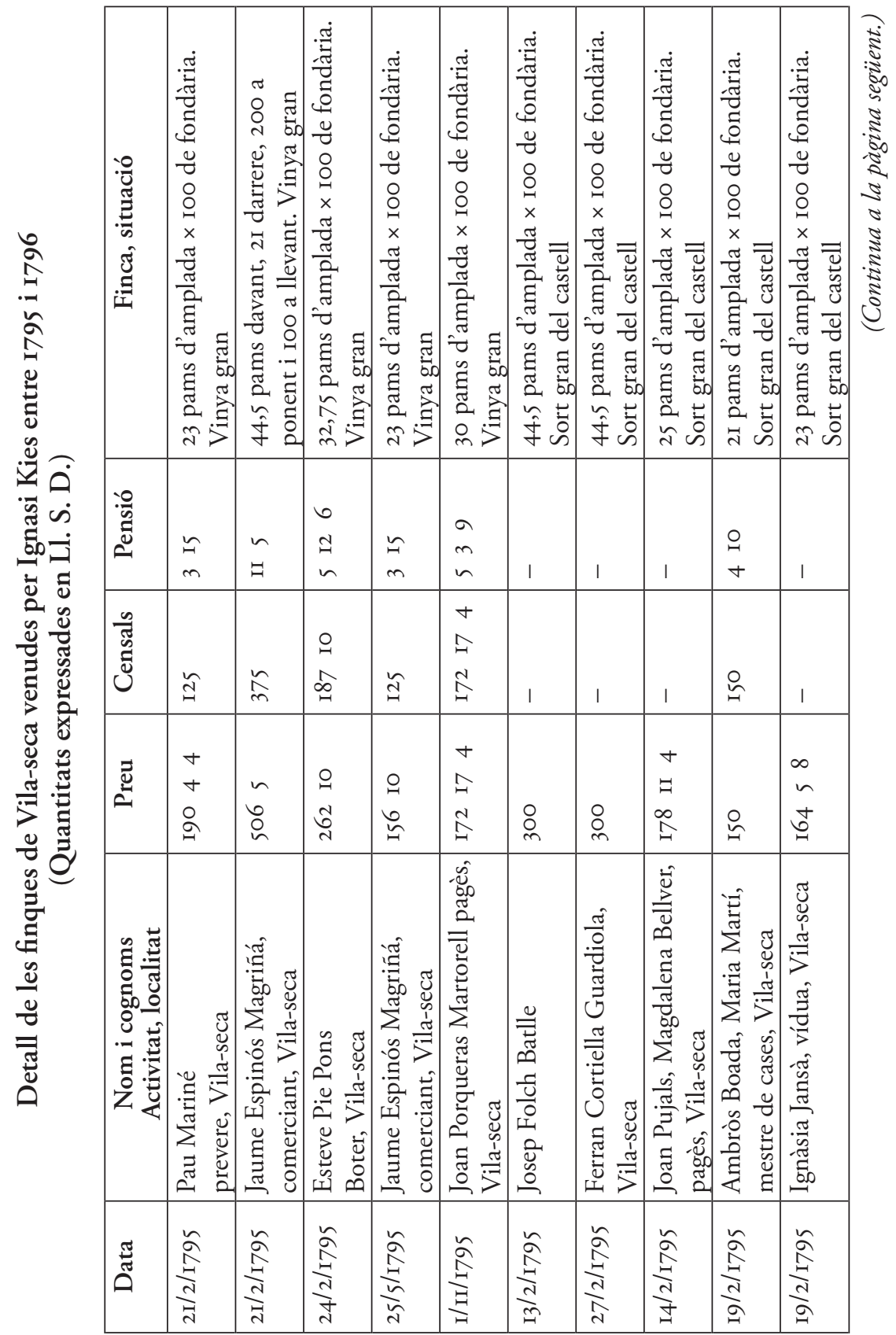

Pedralbes, 39 (2019), I57-I9I, ISSN: O2II-9587, DOI: IO.344/PEDRALBES2OI9.39.6 


\begin{tabular}{|c|c|c|c|c|c|c|c|c|c|c|}
\hline 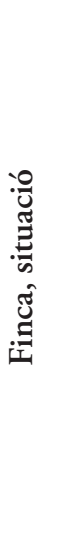 & 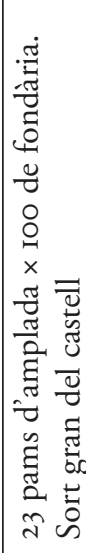 & 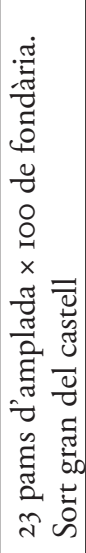 & 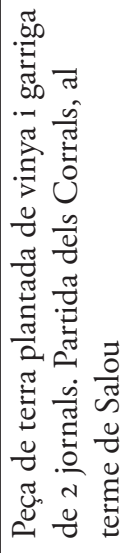 & 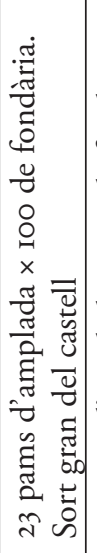 & 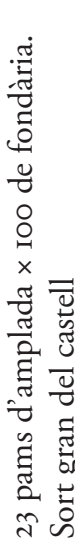 & 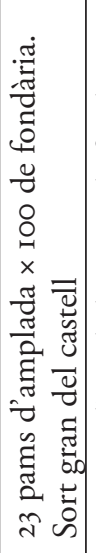 & 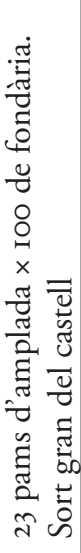 & 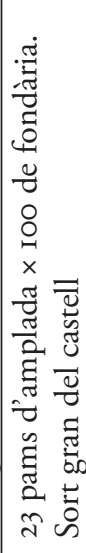 & 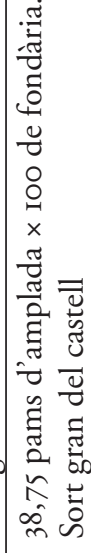 & 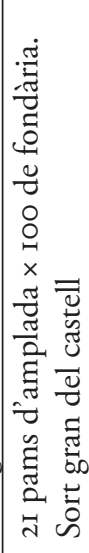 \\
\hline 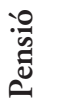 & 1 & $\vec{t}$ & $a$ & $\stackrel{\sim}{+}$ & $\stackrel{-1}{+}$ & + & $\vec{t}$ & I & $\begin{array}{l}m \\
\exists \\
6\end{array}$ & 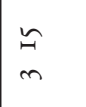 \\
\hline 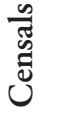 & 1 & $\tilde{\sim}$ & $\begin{array}{l}\text { ㅇ } \\
\text { 으 }\end{array}$ & $\widetilde{\sim}$ & $\tilde{\widetilde{\sigma}}$ & $\tilde{\approx}$ & $\tilde{\oiiint}$ & 1 & \begin{tabular}{l}
$\approx$ \\
$\infty$ \\
\multirow{\sim}{*}{}
\end{tabular} & $\widetilde{\mathcal{G}}$ \\
\hline 离 & 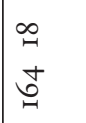 & $\tilde{\approx}$ & ○ & $\tilde{\approx}$ & $\tilde{\approx}$ & $\tilde{\approx}$ & $\tilde{\approx}$ & $\begin{array}{l}n \\
\approx \\
\tilde{o}\end{array}$ & $\begin{array}{l}\approx \\
\infty \\
\underset{\sim}{\sim}\end{array}$ & $\underset{\curvearrowleft}{\stackrel{\circ}{\sim}}$ \\
\hline 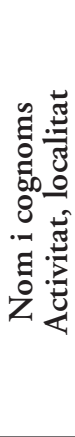 & 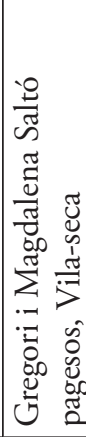 & 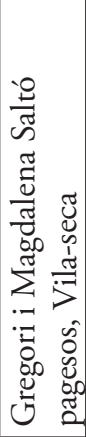 & 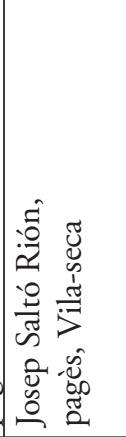 & 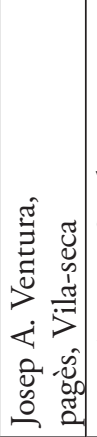 & 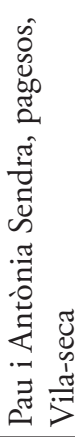 & 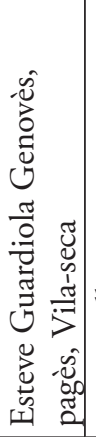 & 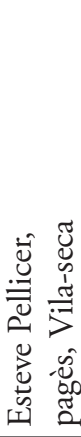 & 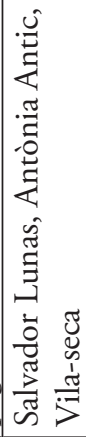 & 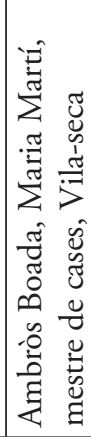 & 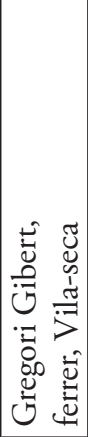 \\
\hline ڤึ & $\frac{n}{\hat{N}}$ & $\frac{\hat{N}}{\frac{\hat{A}}{ה}}$ & $\frac{\tilde{N}}{\frac{n}{n}}$ & 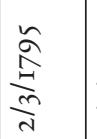 & $\frac{\tilde{\kappa}}{\frac{n}{n}}$ & $\frac{n}{\frac{n}{n}}$ & $\frac{\tilde{\curvearrowright}}{\stackrel{n}{n}}$ & $\frac{\tilde{N}}{\frac{n}{n}}$ & $\frac{\tilde{n}}{\stackrel{n}{n}}$ & $\frac{\hat{\curvearrowright}}{\frac{\hat{n}}{\sigma}}$ \\
\hline
\end{tabular}

Pedralbes, 39 (2019), I57-I9I, ISSN: O2II-9587, DOI: IO.344/PEDRALBES2OI9.39.6 


\begin{tabular}{|c|c|c|c|c|c|c|c|c|c|c|c|}
\hline 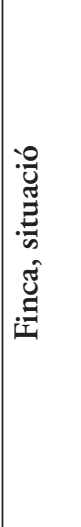 & 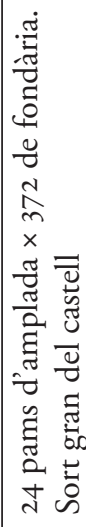 & 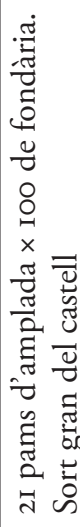 & 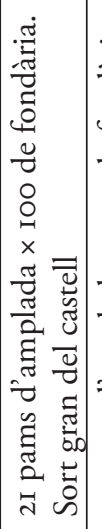 & 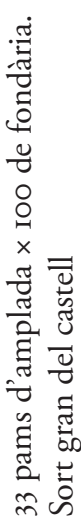 & 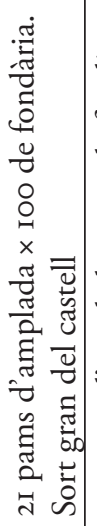 & 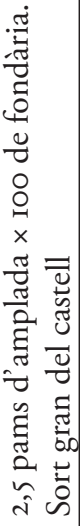 & 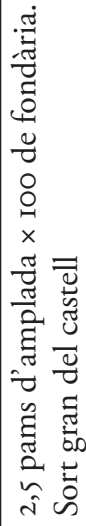 & 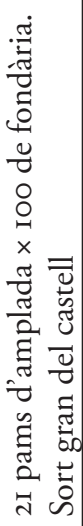 & 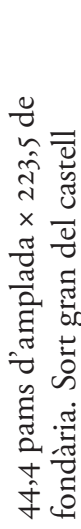 & 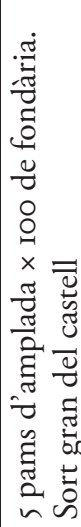 & 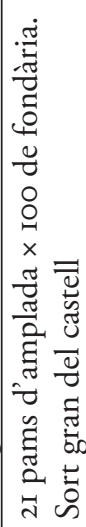 \\
\hline $\begin{array}{c}: \frac{0}{5} \\
\frac{1}{0} \\
0\end{array}$ & $\approx$ & $\begin{array}{l}\approx \\
m\end{array}$ & 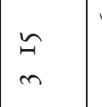 & 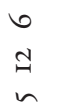 & $\stackrel{n}{\approx}$ & I & 1 & 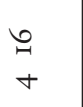 & - & I & $\begin{array}{l}\approx \\
m\end{array}$ \\
\hline 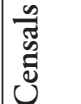 & $\stackrel{\circ}{\circ}$ & $\widetilde{\Xi}$ & $\widetilde{\widetilde{I}}$ & $\begin{array}{c}\stackrel{\rho}{1} \\
\stackrel{0}{\infty}\end{array}$ & $\widetilde{\Xi}$ & I & 1 & 임 & $\tilde{m}$ & I & $\widetilde{\Xi}$ \\
\hline $\overrightarrow{\vec{d}}$ & $\stackrel{\circ}{\circ}$ & $\widetilde{\widetilde{J}}$ & $\widetilde{\Xi}$ & $\begin{array}{l}\sigma \\
N \\
\dot{N}\end{array}$ & $\underset{\sim}{\sim}$ & $\begin{array}{l}\sim \\
\approx \\
\approx\end{array}$ & $\begin{array}{l}\sim \\
\approx \\
\approx\end{array}$ & 인 & $\tilde{m}$ & $\begin{array}{l}\sim \\
\infty \\
\infty \\
m\end{array}$ & $\widetilde{\widetilde{d}}$ \\
\hline 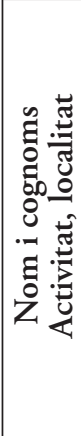 & 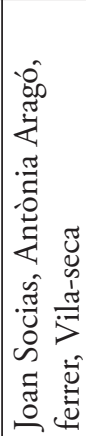 & 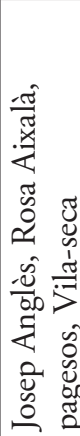 & 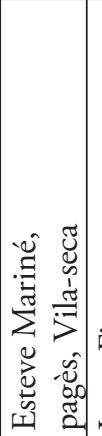 & 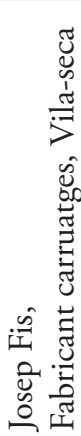 & 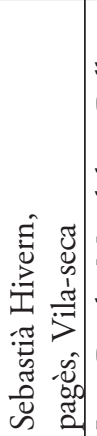 & 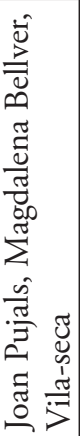 & 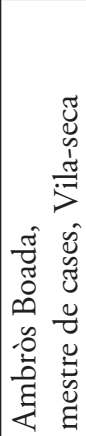 & 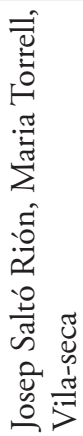 & 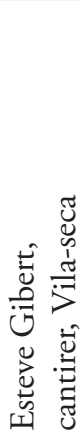 & 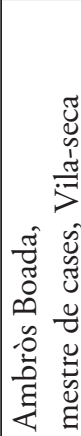 & 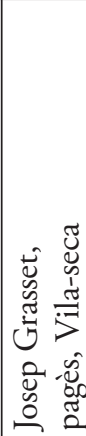 \\
\hline صٌّ & 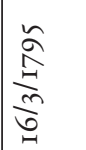 & $\frac{n}{\hat{N}}$ & 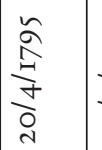 & 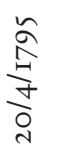 & 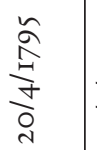 & $\frac{\hat{N}}{\frac{\hat{n}}{n}}$ & $\frac{\tilde{N}}{\frac{\pi}{n}}$ & 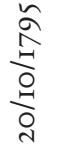 & 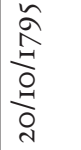 & 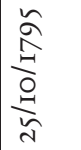 & $\frac{n}{\curvearrowright}$ \\
\hline
\end{tabular}




\begin{tabular}{|c|c|c|c|c|c|c|c|}
\hline 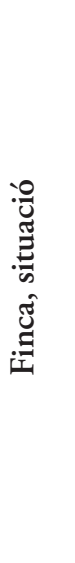 & 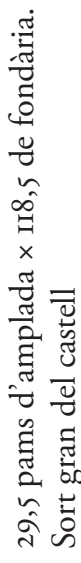 & 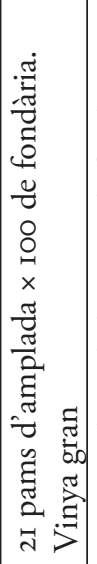 & 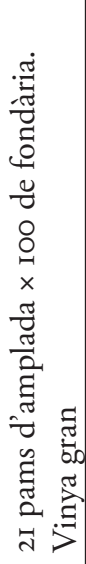 & 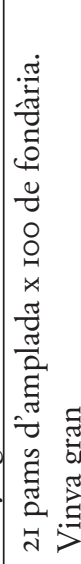 & 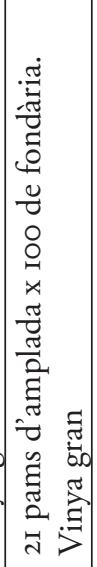 & 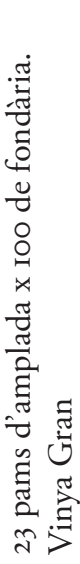 & \\
\hline 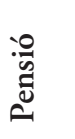 & $\begin{array}{l}a \\
\infty \\
\infty\end{array}$ & $\underset{m}{I}$ & $\begin{array}{l}\stackrel{\odot}{+} \\
+\end{array}$ & $\begin{array}{l}\curvearrowleft \\
\simeq \\
+\end{array}$ & $\approx$ & $\begin{array}{l}a \\
n \\
n\end{array}$ & \begin{tabular}{l}
$m$ \\
\pm \\
\multirow{\sim}{\sim}{} \\
$\sim$
\end{tabular} \\
\hline$\frac{\mathscr{0}}{\mathscr{J}}$ & $\begin{array}{l}\sim \\
\sim \\
\vec{N}\end{array}$ & ㄱ. & $\stackrel{\stackrel{\sim}{\sim}}{\sim}$ & $\underset{\sim}{\sim}$ & $\widetilde{z}$ & $\begin{array}{l}n \\
\stackrel{n}{N}\end{array}$ & \\
\hline 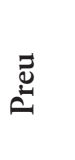 & $\begin{array}{l}N \\
\wedge \\
\vec{N}\end{array}$ & 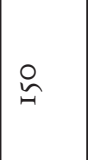 & $\stackrel{\circ}{\sim}$ & $\stackrel{\sim}{\sim}$ & $\widetilde{I}$ & $\begin{array}{l}\infty \\
\stackrel{-}{\circ} \\
\stackrel{-}{\varrho}\end{array}$ & $\begin{array}{l}\infty \\
m \\
0 \\
\infty \\
\infty \\
0\end{array}$ \\
\hline 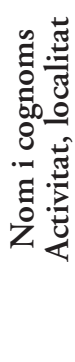 & 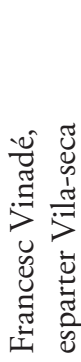 & 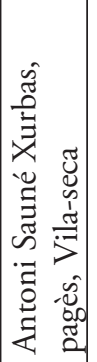 & 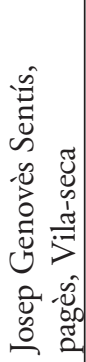 & 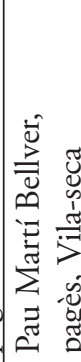 & 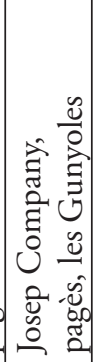 & 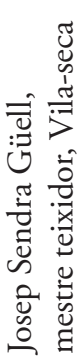 & 퓸 \\
\hline 宽 & $\frac{\tilde{\alpha}}{\stackrel{n}{\Xi}}$ & $\begin{array}{l}\frac{\sigma}{\Omega} \\
\frac{\pi}{n} \\
m\end{array}$ & 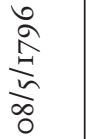 & 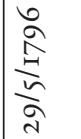 & 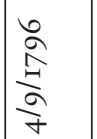 & 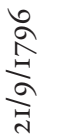 & \\
\hline
\end{tabular}

Pedralbes, 39 (20I9), I57-I9I, ISSN: O2II-9587, DOI: IO.344/PEDRALBES2OI9.39.6 


\section{Conclusions}

L'arribada de Joan Kies, cònsol d'Holanda a Catalunya, va coincidir amb un moment d'expansió comercial holandesa després que la Monarquia Hispànica i Holanda signessin el Tractat de Münster. Lúltim quart del segle xviI, quan el Principat començava a revifar, va ser el moment en què la companyia formada per ell mateix i Arnold de Jäger va assolir una intensa activitat comercial, tant al Mediterrani com a l'Atlàntic, intervenint en múltiples i diverses inversions. La projecció econòmica del Camp de Tarragona justifica que, malgrat que residien a Barcelona, orientessin una part dels seus negocis a aquesta part de Catalunya i s'installessin a Vila-seca.

Al començament del segle XviII, amb la Guerra de Successió de rerefons, la situació de Kies i de la companyia es va complicar. Per una banda, va ser perseguit per la seva adscripció austriacista; per l'altra, la manca de liquidat i la impossibilitat de retornar els crèdits contrets van provocar la fallida de l'empresa; el deute ultrapassava les dues-centes mil lliures. Com succeeix en l'actualitat, es va fer un concurs de creditors que es va allargar fins al I743. Joan Kies havia mort l'agost del 1708.

Pel que fa a la vessant social, tant ell com els seus descendents van emparentar-se amb persones vinculades a la noblesa $\mathrm{o}$ amb càrrecs relacionats amb l'estament eclesiàstic. Joan Kies es va casar amb Maria Àngela Sala, neta de Joan Pere Fontanella, conseller en cap el 1640. En la segona generació, Maria Isabel Kies Sala va contraure matrimoni amb Ramon de Rosselló, noble de Valls, mentre que l'hereu, Antoni, ho va fer amb Raimunda Guasch, filla d'un hisendat d'Alcover i familiar del Sant Ofici. En la tercera, Maria de Rosselló Kies es va casar amb Antoni de Maranyosa, noble ilerdense. Pel que fa als fills d'Antoni Kies, Raimunda i Rosa es van casar amb Francesc Mas i Fèlix Bertran, respectivament, també vinculats a la Inquisició; finalment, Joan Kies va contraure matrimoni amb Francesca Franquès, d'Altafulla.

Després del revés que va patir Joan Kies amb la fallida de la companyia, la possibilitat de conservar les finques de Vila-seca va permetre que els seus descendents del segle xviII poguessin gaudir d'una posició 
econòmica còmoda. Antoni Kies va tenir cura del patrimoni heretat dels seus pares i encara que va realitzar algunes vendes i intercanvis, la finalitat era emprendre altres negocis. Molt diferent va ser la gestió del seu fill Joan, el qual va afegir a les finques de Vila-seca les de la seva mare a Alcover. En els darrers anys de la seva vida, amb l'excusa de millorar les seves propietats i substituir conreus, va demanar diversos préstecs que no va retornar. Alguns d'aquests litigis es van examinar a la Reial Audiència i, malgrat que en un principi el resultat va ser favorable als interessos de la família, les necessitats devien ser tan urgents que, pocs dies després de la mort del seu germà, Ignasi va haver de vendre — en forma de parcel.les_ - algunes de les finques del voltant del castell de Vila-seca i, a causa del divorci, negociar amb la família Franquès la devolució del dot.

En conclusió, ens trobem amb una nissaga que al llarg del segle XVIII va seguir la pràctica endogàmica de les famílies benestants. Pel que fa a la qüestió econòmica, després dels èxits inicials que portaren Joan Kies a Vila-seca, a finals de segle la mala gestió del seu net Joan deixà els seus familiars en una posició difícil. 